relatives who elect to look after them, at incalculable cost to themselves emotionally and very often financially as well. And as a spokesman for a small but worthy battalion of taxpayers his cri-de-coeur should be heard and not lost in the wilderness of politics.

1 The Mental Health of East London, London, Psychiatric Rehabilitation Association, 1968.

${ }^{2}$ Living with Schizophrenia. Surbiton, Surrey, National Schizophrenia

Fellowship, 1974.
B British Medical fournal, 1974, 2, 236.

- Schizophrenia at Home. Surbiton, Surrey, National Schizophrenia Fellowship, 1974.

\section{Screening for Sickle-cell Disease}

Any district hospital in Britain serving a community with a sizeable immigrant population will already practise some form of screening for sickle-cell disease. The minimum requirement is a rapid screening test performed on every Negro patient before general anaesthesia ${ }^{1}$ to ensure that precautions are taken $^{2}$ to avoid factors which may induce sickling.

Screening may be extended, however, to include all patients at risk of a haemoglobinopathy who attend hospital. The tests used will vary with race, but in the case of Negro patients will include haemoglobin electrophoresis and a solubility test for sickle-cell haemoglobin. ${ }^{3}$ When the result is known a diagnostic sticker should be put on the case records, the general practitioner should be informed of the result and its significance, and the patient issued with a medical card. ${ }^{4-6}$ The card should ensure that the next attending doctor or dentist is immediately made aware that the patient has been investigated for an abnormal haemoglobin; this not only prevents rescreening but is of clinical value in surgical, obstetric, and dental mergencies, and after road accidents.

It is equally valuable to the clinician to know that the patient's electrophoresis result was normal, and thus every immigrant patient should ideally be given a card together with an explanation of its significance. The most important-but also the most time consuming-part of the exercise is the explanation given to the patient; without it, the card is never used, and the patient gains nothing apart from anxiety which he did not have before.

This wider type of screening programme has considerable implications for a district hospital serving a large population. The staff of busy surgical, obstetric, and dental clinics are unlikely to have time (or sufficient experience of haemoglobinopathies) to give a detailed explanation to the patient, arrange for the rest of the family to be investigated at a subsequent visit, and offer advice concerning genetic implications. Further problems come when screening is extended outside the hospital to the community, and recent studies in the United States have shown up many of the difficulties. ${ }^{78}$ It is now clear that screening must be preceded by an educational programme to inform the community of the objectives of the study and to allay anxiety about the heterozygous state. The act of screening must never be obligatory, but the individual found to have a positive result should then be offered medical and genetic counselling advice. Genetic counselling is unlikely to achieve any rapid reduction in gene frequency, ${ }^{9}$ and the aim of counselling is to allow two heterozygotes to make an informed decision knowing the risk of giving birth to a clinically affected homozygote. The educational component of these programmes is also of crucial importance in ensuring that the symptomless heterozygote is not at a disadvantage in respect of work or life insurance. It is not yet clear, however, whether community education can reach the level of effectiveness needed for the potential advantages of screening to outweigh the disadvantages.

In the United Kingdom the first priority should be to establish hospital-based haemoglobinopathy clinics in areas with a large immigrant population. Each clinic would generate a nucleus of medical staff with specialist experience in the investigation and clinical management of haemoglobinopathies. The resulting co-ordinated service would raise the standard of supportive care for homozygous patients and would lead to increased awareness of the clinical complications of these disorders. Facilities for family investigations and for genetic counselling should also be provided, and the clinic would thus form a base on which to build future screening programmes.

The number of homozygotes and double heterozygotes in Britain is still small. Co-operative clinical studies between individual haemoglobinopathy clinics would, however, provide a unique opportunity for long-term studies of the natural history and complications of these disorders in a country without tropical disease or the extremes of climate and poverty. Research into the clinical investigation and management of sickle-cell disease and its complications is developing rapidly and was the subject of a recent review. ${ }^{10}$ Double-blind controlled trials designed for the study of sickle-cell crisis ${ }^{11-15}$ should ensure that new anti-sickling agents will be evaluated more rapidly and more objectively than in the past. The value of intrauterine diagnosis to parents who are both heterozygotes has yet to be established, but improved methods for the sampling of fetal blood, ${ }^{16}$ for the separation of fetal and maternal blood by differential agglutination, ${ }^{17}$ and the measurement of small amounts of sickle-cell haemoglobin by radioimmunoassay, ${ }^{18}$ suggest that intrauterine diagnosis may soon become a reality.

The correct sequence in Britain should, therefore, be the formation of an organization of haemoglobinopathy clinics before limited health service resources are allocated to hospital or community screening programmes. District hospitals without such a clinic should be encouraged to establish one in order to provide a service for existing patients, to educate medical and support staff within the hospital and district, and to act as a focus for research studies. That is the quickest way to render obsolete the argument that one should not screen for haemoglobinopathies because there is little to offer the individual at the end of it.

1 British Medical fournal, 1970, 2, 98.

2 Howells, T. H., et al., British fournal of Anaesthesia, 1972, 44, 975.

3 Itano, H. A., and Pauling, L., Blood, 1949, 4, 66.

4 Moran, T. J., Fournal of the American Medical Association, 1972, 219, 204.

Nalbandian, R. M., in Sickle Cell Hemoglobin. Molecule to Man, ed. M. Murayama and R. Nalbandian. Boston, Little, Brown and Co., 1973.

- Stuart, J., et al., British Medical fournal, 1973, 4, 284.

7 Culliton, B. J., Science, 1972, 178, 283.

8 Whitten, C. F., New England Fournal of Medicine, 1973, 288, 318.

- Rucknagel, D. L., Archives of Internal Medicine, 1974, 133, 595.

10 Sickle Cell Symposium, ed. L. S. Lessin and W. N. Jensen, Archives of Internal Medicine, 1974, 133, 529.

11 W.H.O. Scientific Group Report on Treatment of Haemoglobinopathies and Allied Disorders. World Health Organization Technical Report Series, No. 509, 1972.

12 Mann, J. R., et al., Lancet, 1972, 1, 934.

13 Cooperative Urea Trials Group, fournal of the American Medical Association, 1974, 228, 1120.

14 Cooperative Urea Trials Group, fournal of the American Medical Association, 1974, 228, 1125.

15 Cooperative Urea Trials Group, fournal of the American Medical Association, 1974, 228, 1129.

16 Hobbins, J. C., and Mahoney, M. J., New England fournal of Medicine, 1974, 290, 1065.

17 Kan, Y. W., et al., Blood, 1974, 43, 411.

18 Rowley, P. T., et al., Blood, 1974, 43, 607. 